\title{
SEVENTY-FIFTH ANNIVERSARY OF THE FOUNDING OF THE INTERNATIONAL FEDERATION OF RED CROSS AND RED CRESCENT SOCIETIES
}

On 5 May last the International Red Cross and Red Crescent Movement celebrated the 75th anniversary of the International Federation of Red Cross and Red Crescent Societies.

On the same date in 1919 five Red Cross Societies - those of France, Great Britain, Italy, Japan and the United States of America - set up the League of Red Cross Societies. Its purpose was to "unite Red Cross Societies throughout the world in a concerted effort to prevent, mitigate and alleviate the suffering caused by disease and major disasters". ${ }^{\prime}$

This event, which took place at the initiative of Mr Henry P. Davison, President of the American Red Cross War Council, corresponded to the wish of several National Societies to "prepare and submit to Red Cross Societies throughout the world an extended programme of action in the general interest of humanity".

The Cannes medical conference, held at the Cannes Nautical Circle from 1 to 11 April 1919, was a milestone in the setting up of the League of Red Cross Societies. It brought together some 60 eminent American, British, French and Japanese specialists in preventive medicine, child health, tuberculosis and nursing care who laid the foundations for the humanitarian work which the League, now known as the Federation, has been carrying out worldwide for three-quarters of a century.

\section{Commemorative plaques}

Geneva, Cannes and Paris can be considered as having played a key role in the founding and setting up of the League of Red Cross Societies in 1919. In

\footnotetext{
'Excerpt from the Bulletin de la Ligue des Sociétés de la Croix-Rouge, Vol. I, No. 1, 15 May 1919.
} 
recognition of that role the Henry Dunant Society of Geneva presented the three cities with commemorative plaques to be laid at sites associated with this historic event.

Thus on 1 February 1994, exactly 75 years after a Committee of Red Cross Societies had been formed in Cannes to set up programmes for Red Cross activities in peacetime, a commemorative plaque was affixed to the Maison Mallet in Geneva, the League's first world headquarters. A second plaque was laid in Cannes on 9 April to mark the 75th anniversary of the medical conference and a third was unveiled on 5 May at the Hotel Regina in Paris, where the League was officially set up. These events were attended by local authorities of the three cities and representatives of the Federation, the ICRC, various National Societies. the Henry Dunant Society and the Association Henry Dunant/France.

The Henry Dunant Society has also published a book entitled "The Cannes Medical Conference", which contains the speeches delivered at the ceremony held on 9 April when a commemorative plaque was laid at the Cannes town hall. and various articles contributed by specialists and public figures about Cannes. the Nautical Circle and the medical conference. In addition, the Society is preparing an historical work entitled "The seventy-fifth anniversary of the founding of the League of Red Cross Societies", which will contain papers retracing the League's origins, articles about the activities of the institutions concerned and the speeches delivered on 5 May at the Hotel Regina. The Review' will publish accounts of these two works in a forthcoming issue.

\section{Official celebration (Paris, 5 May 1994)}

The official celebration of the founding of the Federation took place in Paris on 5 May. It was attended by delegations of 70 National Societies, including the five co-founders, and representatives of the Federation and the ICRC. To mark the occasion the French Red Cross, in cooperation with the Federation, organized several ceremonies in which the French authorities took an active part.

On 4 May the members of the Federation's Executive Council, the heads of National Society delegations and the members of the ICRC were received at the Elysée Palace by the President of the French Republic, Mr François Mitterrand. who spoke of the Federation's "invaluable role".

The commemorative ceremony took place at the Ministry of Foreign Affairs in the presence of Mr Philippe Douste-Blazy, Minister Delegate attached to the Ministry of Health. After a welcoming address delivered by Professor André Delaude, President of the French Red Cross, Lady Limerick, a Vice-President of the Federation and Chairman of the British Red Cross, took the floor on behalf of the National Societies. Lady Limerick outlined the circumstances in which the League was set up in 1919 and gave an overvicw of the Federation's past and present activities, then concluded her talk with the following words: "The 